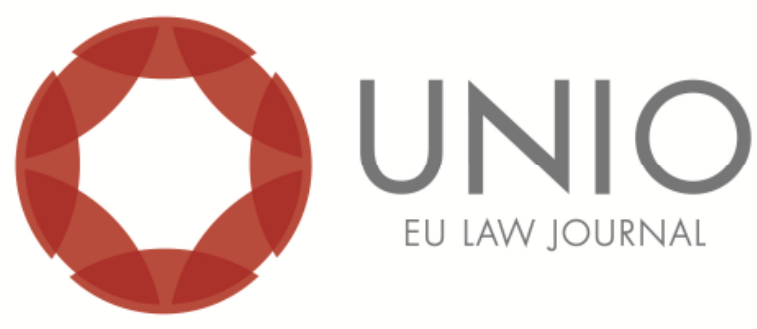

\title{
The Early Days of the Euro Debt Crisis Revisited: Historical, Legal and Institutional Overview of the Role of the ECB in the Context of an Economic and Monetary Union in Mutation
}

\author{
Rui do Carmo*
}

ABSTRACT: This paper seeks to shed some light on the different stages of what ended up being a deep euro debt crisis of unforeseen proportions and the attempts of responses designed to address it in the context of an EU, unprepared to face its outcomes and implications. Our starting point is a quick overview of the historical, institutional and legal pathway that led to the set-up of the EMU, seeking to provide a better understanding of the backdrop for the on-going euro crisis and the several legal instruments put forward within and alongside the EMU framework to tackle it. Particular attention is given to the functions and goals originally attributed to the ECB and to some of the controversial steps this institution decided to take in order to address the debt crisis at its different stages. Finally, some lines of reflexion are proposed in light of the future challenges that we consider that an EMU in mutation inevitably entails.

KEYWORDS: euro debt crisis - Economic and Monetary Union - European Central Bank euro.

\footnotetext{
* Collaborating Member of the Centre of Studies in European Union Law of University of Minho.
} 


\section{Paving the way to a monetary union}

The European Economic and Monetary Union (EMU), commonly regarded as a milestone in the history of European integration, is not usually pinpointed as a highlight of the reasoning of the founding fathers reflected in the original scope of the Treaties of Rome ${ }^{1}$. However, the events that would take place in the decades following the signature of these Treaties, would eventually translate into a clear path to the adoption of a single currency and the establishment of the $\mathrm{EMU}^{2}$.

From the early 1950s onwards, an intergovernmental union - the European Payments Union (EPU) - was already serving as a clearing house for payments and short-term credit. ${ }^{3}$. The European Economic Community (EEC) came then to establish a new legal and institutional framework that, although guaranteeing that Members States would still retain broad control of their economic and monetary policies, envisaged their coordination insofar as necessary to achieve the Treaty objectives ${ }^{4}$, which entailed cooperation between their central banks ${ }^{5}$ and regarding exchange rate policies as a matter of common concern ${ }^{6}$.

In 1959, the EPU was replaced by the European Monetary Agreement $(\mathrm{EMA})^{7}$, just one year after the creation of the European Investment Bank $(\mathrm{EIB})^{8}$. From 1960 to 1962 the Council enacted the First ${ }^{9}$ and the Second Capital Directives $^{10}$. Additionally, during the 1960s, the Commission would manifest the intention of putting forward concrete proposals regarding the introduction of a monetary union ${ }^{11}$ but would not come through with them in the following years essentially due to political and economic instability.

In 1968, however, the Barre Plan recommended the establishment of Community machinery for monetary cooperation, along with convergence of national medium-term economic policy orientation and closer coordination of short-term economic policies ${ }^{12}$. The debate that followed uncovered straight away the opposite points of view that would mark this issue for years to come,

1 The Treaty establishing the European Economic Community (EEC) and the Treaty establishing the European Atomic Energy Community (Euratom), entered into force on 1 January 1958 and added to the European Coal and Steel Community (ECSC), established in 1952 for a period of 50 years.

${ }^{2}$ For a full chronology and description of the events regarding the set-up of the European Monetary Union see H. K. Scheller, The European Central Bank - History, Role and Functions, (Frankfurt am Main: ECB edition, 2006), and H. Ungerer, A Concise History of European Monetary Integration - From EPU to EMU (Westport: Quorum Books, 1997).

3 Accord sur l'établishment d'une Union européenne de paiements du 19 septembre 1950 (Organisation européenne de cooperation économique, 1954).

${ }^{4}$ See Article 6(1) EEC.

${ }^{5}$ See Article 105(1) first para. EEC.

${ }^{6}$ See Article 107(1) EEC.

7 Accord monetaire europeén du 5 aout 1955 amendé par les Protocoles additionelles Nos 2 et 3 et les Décisions prises par l'Organisation européenne de cooperation économique jusqu'au 1er août 1960 (OECE, 1960).

${ }^{8}$ EEC Treaty - Protocol on the Statute of the European Investment Bank.

${ }^{9}$ First Council Directive for the implementation of Article 67 of the EEC Treaty (liberalisation of capital movements), 1960 O.J. L 921/60.

10 Second Council Directive 63/21/EEC, 1963 O.J. L 62/63.

11 In this regard see in particular "Initiative 1964," Official Spokesman of the Commission, Information memo P-59/64 (Brussels, October 1964), 4-5.

${ }^{12}$ ECSC-EEC-EAEC Secretariat General of the Commission, "Commission Memorandum to the Council on the Co-ordination of Economic Policies and Monetary Co-operation within the Community," Supplement to Bulletin of the European Communities, No 3-1969 (Publishing Services of the European Communities, 1969). 
and that, to a certain extent, still remain; namely, in what regards the opposition between "economists" and "monetarists" 13 , and between those who opposed the plan stressing that monetary and political union are linked by nature, and others who supported it precisely because the enhanced economic cooperation it entailed entailed would be a way forward towards greater political integration. Moreover, such debate and political backdrop would make clear the limits of the EEC competences and the fragmented character of the economic and monetary policies policies comprised therein ${ }^{14}$.

In 1970 the Werner Committee was created mainly as the outcome of the joint joint efforts from Germany, Luxembourg and Belgium to put forward plans for a a monetary union to be set up by stages. The Committee proposed the full setting setting of an EMU until the end of the $1970 \mathrm{~s}^{15}$.

Moreover, from the 1970s onwards, narrowing exchange rates was perceived as a as a pivotal way to achieve monetary integration ${ }^{16}$. It was against this backdrop that that the fixed exchange rate system collapsed in the summer of 1971, giving place to place to the creation of the European "currency snake"17 (a mechanism whereby currencies were allowed to fluctuate within limited margins) in March 1972, which which would quickly prove to be ineffective. Additionally, the collapse of Bretton Bretton Woods resulted in the subsidence of the European fixed rate system and the abandoning of the "snake", by the Council, would shortly follow, in March 1973. In 1975 the European Unit of Account (EUA) was created as a basket currency. It comprised fixed amounts of each currency of the different EEC Member States. A few years later, in 1978, the European Monetary System (EMS) (EMS) was finally set up, as of $1979^{18}$, using the European Count Unit (ECU), replacing the EUA, as base of the exchange rate mechanism (ERM). The UK decided not to join the EMS.

Despite the step forward that the EMS and the ECU represented in terms of monetary integration, additional incremental changes would have to take place in order to turn the single currency goal into reality. One of the steps that became instrumental in doing so was the adoption of the Single European Act (SEA) ${ }^{19}$. Signed in February 1986 and entered into force on 1 July 1987, it introduced the Single Market as a further Community goal and the necessary decision-making changes to complete it, therefore reinforcing the Community's capacity for achieving economic and monetary union.

1988 brought along the Third Capital Directive ${ }^{20}$ (that, together with the ERM, substantially reduced the national monetary policy powers of the governments), and separate proposals from Italy and France aimed at the creation of a European central bank and of a single currency, following what had been put forward by the

\footnotetext{
$\overline{13}$ The first group was in favour of moving to an economic union first while the second gave priority to the monetary union.

14 As noted in particular by G. G. Rosenthal, The Men Bebind the Decisions: Cases in European PolicyMaking (New York: Lexington Books, 1975), 102-105.

15 Cf. Rapport au Counseil et á la Commission concernant la realization par étapes de l'union économique et monétaire dans la Communauté, 1970 J.O. C136/1.

16 E. Mourlon-Druol, "The Euro Crisis: a Historical Perspective," Strategic Update - IDEAS, London School of Economics and Political Sciences (2011): 7.

${ }_{17}$ See (1972) O.J. C38/3.

18 Resolution of the European Council on the establishment of the European Monetary System (EMS) and related matters of 5 December 1978.

${ }^{19}$ Single European Act, 1987 O.J. L 169/1 (amending the EEC Treaty).

${ }^{20}$ Council Directive 88/361/EC, 1988 O.J. L 178/5.
} 
Commission in its internal market White Paper ${ }^{21}$, in 1985.

In 1989, the Committee that was set up for that purpose, the Delors presented a Report ${ }^{22}$ proposing the creation of the EMU in a three-stage process: closer coordination of economic and monetary policies, creation of the Central Bank (ECB), and replacement of national currencies by a single currency.

The first stage took place from 1 July 1990 to 31 December $1993^{23}$ having established within the existing institutional framework of the Community. the second and third stages would require further alterations of this institutional framework therefore entailing a revision of the EEC Treaty through a intergovernmental conference (IGC).

\section{Maastricht, the ECB and a single currency}

The most prominent outcome of the IGC negotiations was the Treaty on European Union ${ }^{24}$ (commonly known as the "Maastricht Treaty"). It established the European Union and amended the founding treaties of the European Communities including in what regards the addition of a new chapter on economic and monetary policy laying down the foundations of the EMU and setting out a methodology and a timetable to accomplish it. The empowered EEC would thereinafter be known as European Community (EC).

With the creation, on 1 June 1998, of the European System of Central Banks (ESCB) and the ECB, designed to head the system, the Treaty entrusted the latter institution with the responsibility for monetary policy, but it did not provide it with supervisory powers or an explicit mandate for giving emergency liquidity support to individual banks. Therefore, national authorities remained responsible for financial stability and, as a result, in the euro area, some bank regulatory functions were centralised, while others were under the scope of several national regulators. Overall, monetary policy was imminently supranational while on the subject of economic policy, EC powers were limited to the coordination of the different national policies ${ }^{25}$.

Moreover the principles of sound public finances and monetary conditions, stable prices and a sustainable balance of payments that had already been addressed with the Delors Report ${ }^{26}$ were perceived as structurally fundamental to the establishment of the EMU. In line with this reasoning reflected in the Broad Economic Policy Guidelines (BEPG) and the Excessive Deficit Procedure (EDP) ${ }^{27}$ provided by the EC Treaty, Germany proposed, in 1995, the creation of additional mechanisms designed to control Member States' public spending. Such proposals and the debate that followed culminated in the creation of the Stability and Growth Pact (SGP) ${ }^{28}$ that would come to be a highly controversial

${ }^{21}$ Commission of the European Communities, Completing the Internal Market: White paper from the Commission to the Council (Office of the Official Publications of the EC, 1985).

${ }^{22}$ Committeee for the Study of Economic and Monetary Union (The Delors Committee), Report on Economic and Monetary Union in the Community (Office for the Official Publications, 1989).

${ }_{23}$ Madrid European Council, 26-27 June, Conclusions of the Presidency, Bulletin of the European Communities No 6. (1.1.11).

24 Treaty on European Union (Maastricht text), 29 July 1992, O.J. C 191/1.

25 See in particular Articles 99, 105, 105c and 107 EC.

${ }^{26}$ Cf. the Delors Committee Report (supra ${ }^{22}$ ) in particular paragraphs [19], [29], [30] and [59], pp. 14, 18-20, 35-36.

${ }^{27}$ See Article 104c EC and the Protocol on the Excessive Deficit Procedure, cf. infra ${ }^{28}$ and ${ }^{61}$.

${ }^{28}$ Cf. Resolution of the European Council on the Stability and Growth Pact, 17 June 1997, 1997 O.J.

C 236, Council Regulation 1466/97/EC on the strengthening of the surveillance of budgetary 
aspect of the EMU.

The Treaty of Nice $^{29}$ did not significantly change the framework provided by the the previous Treaties. The Treaty of Lisbon ${ }^{30}$ seemed unlikely to be recorded in history as a particularly memorable chapter of the $\mathrm{EMU}^{31}$. similar to the previous treaties, it makes a sharp distinction between economic ${ }^{32}$ and monetary policy ${ }^{33}$, allocating them different powers and goals ${ }^{34}$. The emphasis is made on coordination coordination of policies and compromise regarding economic policy, without any any explicit provision for neither shared nor exclusive competences ${ }^{35}$. Differently, in Differently, in matters of monetary policy, the Union has exclusive competences for for the countries using the euro - the so-called "Ins"36 - , while the "Outs" keep their their monetary policy competences.

The Treaty also provides that the ECB - an institution with a legal personality ${ }^{37}$, personality ${ }^{37}$, now ranks among the other Union institutions in the TEU $^{38}$, together together with the national central banks (NCBs) of the eurozone (with which comprises the Eurosystem) - is responsible for conducting the monetary policy of the Union ${ }^{39}$. There is also a new chapter on provisions dedicated to the eurozone countries $^{40}$ and a new Protocol consecrating the existence of the Euro Group ${ }^{41}$.

\section{The mandate and independence of the ECB in the context of the legal and institutional frameworks of the EMU}

As it has been mentioned, the EMU comprised, through the Treaties, and since Maastricht, two different sets of rules and goals determining Union competences in the fields of economic and monetary policies. Member States retained authority for both fiscal and economic policies, although within an EU coordination framework while, on the other hand, monetary policy involved Union legally binding measures. In this context, the ESCB and the ECB had been set up as a complex mixture of both supranationalism and intergovernmentalism and of "hard law" and "soft

positions and the surveillance and coordination of economic policies, 1997 O.J. L 209, and Council Regulation 1467/97/EC on speeding up and clarifying the implementation of the excessive deficit procedure, 1997 O.J. L 209; cf. infra ${ }^{60}$.

${ }^{29}$ Treaty of Nice, amending the Treaty on European Union, the Treaties Establishing the European Communities and Certain Related Acts, 11 December 2000, O.J. C80 of 10 March 2001; 2001/C $80 / 01$.

30 Treaty of Lisbon, amending the Treaty on European Union and the Treaty Establishing the European Community, 13 December 2007, 2007/C 306/01. The Treaty of Lisbon has renamed the previous treaties as the Consolidated versions of the Treaty on European Union (TEU) and the Treaty on the Functioning of the European Union (TFEU).

31 B. Frankal, I.A. Oleaga and W. Coussens, "How Will the Lisbon Treaty Affect EMU?," EUREDIA 2007-2008/2 (2008): 158.

32 See Articles 119-126 TFEU.

33 See Articles 127-133 TFEU.

${ }^{34}$ For an overview of the changes on EMU introduced by the Treaty of Lisbon cf. S.M. Seyad, "The Lisbon Treaty and EMU," European Policy Analysis, Swedish Institute for European Political Studies (2008).

35 See Article 2(3) TFEU.

36 See Article 3(1)(c) TFEU.

${ }^{37}$ See Article 282(3) TFEU.

38 See Article 13(1) TEU.

${ }^{39}$ See Article 282(1) TFEU.

40 See Chapter 4, Provisions specific to Member States whose currency is the euro, Articles 136 to 138 TFEU.

${ }^{41}$ See Protocol (No 14) on the Euro Group, TFEU. 
law" $" 42$.

Within this legal framework, price stability was laid down as ESCB's (and accordingly ECB's) primary goal, complemented, insofar as it has been accomplished, with support to the general economic policies in the Union ${ }^{43}$. This hierarchy of objectives had been introduced to avoid any misunderstanding the core macroeconomic objective and mandate of the ECB that seemed, to come across quite clear from the outset. This aim would necessarily also ensuring smooth operation of the eurozone payment system and money In practice, the ECB came to be very successful in achieving price stability when looking at the euro area as a whole, although it was largely debated if price is the only proper goal for central banks ${ }^{45}$. The way the ECB chose to this goal, met a certain degree of approval during the first years of its existence which, some claim, was extremely important for establishing the euro as a successful and stable currency over the pre-crisis period ${ }^{46}$.

The definition of price stability as the primary objective of the ESCB was a result of the influence of the German model over the EMU setting up process, entailing a strict reading of the ECB's independence perceived as a necessary condition for that objective to be achieved and maintained, shielded from policymakers' demands to exploit monetary policy for short-term electoral gains to inflate national debt ${ }^{47}$. In fact, some considered that the high degree of institutional independence granted to the ECB in pursuing this mandate was probably the strongest feature of the architecture of the EMU ${ }^{48}$. According to this line of reasoning, for an independent central bank to succeed in maintaining price stability, it suffices to be credible and supported by important stakeholders such as policy makers, economic experts, financial markets actors, and social partners ${ }^{49}$.

The arguably close relationship between central bank independence and monetary stability that we have been referring to ${ }^{50}$ is also supported by the reasoning that the more varied the goals to be achieved by a central bank, the less independence it holds. Overall, it clearly results in a situation whereby a monetarist approach influenced the backdrop of the monetary policy within the EU by linking the ECB's mandate and goals to monetary stability ${ }^{51}$, and by shielding it through Article 130 TFEU which states that neither the ECB nor the NCBs shall seek or take instructions from Union institutions or national

\footnotetext{
$\overline{42}$ For an overview of the original set up of the ESCB cf. M. Seidel, "The Constitutional Design of the European Central Bank" in The Decision Rules of the European Central Bank, CESinfo, Journal for International Comparison, 10-1 (2011):14-18.

${ }^{43}$ See Article 127(1) TFEU.

${ }^{44}$ E. Baltensperger, "Assessing the European Central Bank's Euro Crisis Policies" in The Decision Rules of the European Central Bank, CESifo DICE, Journal for International Comparison: 10-1:8-13 (2011), 9.

45 With this particular perspective cf., e.g., A. Orphanides, "Monetary policy lessons from the crisis," Central Bank of Cyprus Working Paper 2010-1 (2010); and M. King, "Do Inflation Targets Work?," London: Centre for Economic Policy Research (2008).

${ }^{46}$ Baltensperger, "Euro Crisis Policies," 9.

47 Paul De Grauwe. Economics of Monetary Union (Oxford: Oxford University Press, 2009), 163.

${ }^{48}$ Baltensperger, "Euro Crisis Policies," 9.

49 Cf., e.g. Erik Jones, "Output Legitimacy and the Global Financial Crisis: Perceptions Matter," JCMS: Journal of Common Market Studies 47(5) (2009): 1085-1105.

${ }^{50}$ For a detailed analysis of the interconnection between these two parameters cf., e.g., A. Alesina and L. H. Summers, "Central Bank Independence and Macroeconomic Performance: Some Comparative Evidence,” Journal of Money, Credit and Banking, 25(2) (1993): 151-162.

${ }^{51}$ See Article 127(1) TFEU.
} 
bodies $^{52}$. Therefore, the ECB enjoys a legally conformed independence from governments and parliaments when pursuing the mandate laid down in the Treaty, Treaty, reinforcing the idea of a stronger separation from the pressures resulting from variable political and opportunistic cycles ${ }^{53}$.

Additionally, the ECB's independence guaranteed by the legal framework of the Treaty, also regards the determination of the content of price stability itself and the fact that other national and EU institutions have neither voting rights in its decision-making process nor in reviewing or suspending its legal decisions, in line with the above mentioned protection conferred by Article 130 TFEU. Moreover, it should not be forgotten that the ECB has the legal capacity to independently complete its duties derived both from its legal personality under public international law and from the set of original competences laid down in the context of the Union that are not dependent or derived from other Union institutions.

However, and notwithstanding what has been mentioned, it should also be stressed that the ECB, although functionally independent, is subject to primary and and secondary EU law, being an integral (not autonomous) part of the Union, therefore submitted to the obligation of loyal cooperation between EU institutions. institutions. This was, in fact, how the Court of Justice ruled in 2003 when confronted with a case concerning the applicability, to the ECB, of EU legislation on anti-fraud investigations ${ }^{54}$.

Another layer of this debate concerns the supranational character of the $\mathrm{ECB}^{55}$. In fact, this institution's set up seems to incorporate some features normally associated with central banks of large and heterogeneous areas namely in what regards the size of the monetary policy decision-making body, the ECB's Governing Council, which currently consists of the six members of the Executive Board and the governors of the national central banks of the 19 euro area countries. Additionally, the ECB is also one of the few central banks that requires that decision-makers have a specific regional background, at the level of its Governing Council $^{56}$. As mentioned, the majority of seats are allocated by country, with each euro area member having exactly one representative. Overall, these institutional characteristics should mount up to a system where ECB-related decisions would be made with a purely Unionist mindset. Nonetheless, some have pointed out that

\footnotetext{
52 Article 130 TFEU states that "When exercising the powers and carrying out the tasks and duties conferred upon them by the Treaties and the Statute of the ESCB and of the ECB, neither the European Central Bank, nor a national central bank, nor any member of their decision-making bodies shall seek or take instructions from Union institutions, bodies, offices or agencies, from any government of a Member State or from any other body. The Union institutions, bodies, offices or agencies and the governments of the Member States undertake to respect this principle and not to seek to influence the members of the decision-making bodies of the European Central Bank or of the national central banks in the performance of their tasks."

${ }^{3}$ Cf. in particular A. Alesina and A. Stella, "The Politics of Monetary Policy,” NBER Working Paper No. 15856 (2009).

${ }^{54}$ Cf. Judgment OLAF, 10 July 2003, Case C-11/00; cf. for a detailed analysis of this judgment R.J. Goebel, "Court of Justice Oversight Over the European Central Bank: Delimiting the ECB's Constitutional Autonomy and Independence in the OLAF Judgment", Fordham International Law Journal, 29:4, (2005); 610-654; and also Chiara Zilioli and Martin Selmayr, "The Constitutional Status of the European Central Bank," (44) Common Market Law Review, Issue 2 (2007): 355-399.

55 For a comprehensive view on the supranational character of the ECB cf. H. Badinger and V. Nitsch, "National Representation in Multinational Institutions: The Case of the European Central Bank," CESifo Working Paper no. 3573 (2011).

${ }^{56}$ H. Badinger, and V. Nitsch, "Supranationalism in Monetary Policy Decision Making," in The Decision Rules of the European Central Bank, CESifo DICE, Journal for International Comparison: 10 1:27-31. (2011): 27.
} 
such assumption might be, to a certain extent, quite naive ${ }^{57}$.

The overview done so far along with the remarks summarised regarding the origin, independence and mandate of the ECB within the framework of the EU, become particularly important when tackling the cascade of events that characterised the most recent years of the EMU, as we are about to do. In fact, from August 2007 "the world was struck by a full-blown systemic financial crisis, unprecedented in terms of financial losses and fiscal costs, in its geographical across mostly developed economies, in its speed and its globally synchronised nature" 58 that grew into a serious sovereign debt crisis across the euro zone, to test the described legal, political and institutional frameworks of the EMU.

\section{From a financial to a sovereign debt crisis: chronology of a legal and institutional maze ${ }^{59}$}

The vast majority of public opinion will most likely pinpoint the fall of Lehman Brothers on 15 September 2008 as the event that unfolded the crisis that would linger in the agenda of the media ever since. However, the first reports of substantial losses suffered by European banks resulting from the involvement in sub-prime related schemes date back to July 2007 with the consequent progressive loss of market confidence in the soundness of financial institutions. The announcement of freezing of funds by BNP Paribas, on 9 August 2007, is one of the most prominent events that can be recalled from that period. In fact, in the same month, more than one year before the Lehman Brothers related frenzy, the ECB announced that it had already provided 95 billion euros of liquidity to banks, a first EU response to an unfolding financial crisis of unparalleled proportions and consequences. Bank-runs and the collapse of cross-border and national financial institutions, along with all the resulting detrimental domino effects, came to put to test the described framework provided by the EMU, the euro and, of course, the role of the ECB itself in the context of an EU caught off-guard by the institutional, political and legal challenges it would soon have to face.

Moreover, with the registered and on-going impact in several eurozone countries, of which Greece is only the most prominent example, and the unfolding of what would soon clearly come across as a sovereign debt crisis of a more structural nature, the institutions have been struggling to find a clear path to overcome the medium and long term effects of the situation and re-establish a balance within the array of available legal and institutional instruments or, alternatively, to come up with new ones.

In fact, the period that preceded and immediately followed the fall of Lehman Brothers lacked a coordinated Union-level approach to the emerging problems which were therefore tackled essentially at the level of the national euro area Member States throughout the years of 2008 and 2009. The first measures that they put forward in trying to protect their own financial systems included bank rescues, deposit guarantees and a succession of public attempts to ease the

\footnotetext{
${ }^{57}$ Badinger, "Policy Decision Making," 27 and 29.

${ }^{58}$ J. Stark, A. Jung, and F. Paolo Mongelli, "Normal Times Versus Crisis Times," in The Decision Rules of the European Central Bank, CESifo DICE Report - Journal of International Comparisons. 10, 1: 3-8. (2012): 3 .

${ }^{59}$ For a full chronology and description of the early stages of the global financial crisis, see the $79^{\text {th }}$ Annual Report of the Bank for International Settlements, Basel, 29 June 2009, accessed April 10, 2015, available at http://www.bis.org/publ/arpdf/ar2009e0.pdf.
} 
increasing worries of bank depositors. It naturally follows that these measures ended up having a significant impact on the balance sheets of the Members States States that suffered as an outcome of the efforts to control the financial contagion contagion resulting from the potential systemic risk that the collapse of each financial institution could entail and of which Ireland's unlimited guarantee of deposits in its national banks is an outstanding example. Additionally, the impact of of these national measures in the increasingly growing sovereign debts was in fact in fact in contradiction with the rules and principles that, as we have seen, characterised the design of the single market.

Consequently, by September 2008, such efforts and their impact on the national budgets had already mounted up to a problem of extreme proportions that sooner or later would demand supranational financial assistance in a context where there was neither a legal basis to do so at the Union level nor political will, on the part of the Member States' governments, to reach an agreement that could be used as an umbrella for maximalist solutions to the escalating sovereign debt crisis.

Such fact resulted from a conscious choice, set up under the framework of the $\mathrm{SGP}^{60}$, the $\mathrm{EDP}^{61}$ and market discipline, along with the limitation of the "no bailout" principle, laid down in Article $125 \mathrm{TFEU}^{62}$, to prevent the Union or any Member State from being liable for or assume the commitments of another Member State. In other words, the EMU framework established in the TFEU entailed that each Member State is exclusively responsible for its fiscal problems. Therefore, in the absence of a safeguard mechanism at the Union level, any subsequent need for financial rescue on the part of a Member State would most likely have to rely on the structural conditionality model of assistance of the International Monetary Fund (IMF $)^{63}$ : credit line in exchange for structural reforms, Memorandum of Understanding and periodic reviews on which further credit would depend.

That was, in fact, what happened with Greece in May 2010, when this Member State became increasingly unable to fund itself in the markets and was provided

${ }^{60}$ Cf. supra ${ }^{28}$; the SGP is currently based on Articles 121 and 126 TFEU; the 1997 original version underwent modifications in 2005 due chiefly to pressures from Germany and France, in order to render it more flexible and enforceable without changing the deficit limit values established therein (cf. Council Regulation (EC) No 1055/2005 and Council Regulation (EC) No 1056/2005, both of 27 June 2005); the evolving circumstances arising from the sovereign debt crisis resulted in alterations of the SGP legal framework after 2011, through several legal instruments namely the "European semester," the "six pack" and the "Euro Plus Pact"; cf. infra ${ }^{74},{ }^{75}$ and ${ }^{76}$.

${ }^{61}$ Cf. supra ${ }^{27}$; currently based on Article 126 TFEU and Protocol (No 12) on the Excessive Deficit Procedure, TFEU.

${ }^{62}$ Article 125(1) TFEU, commonly known as the "no bail-out clause" states that "The Union shall not be liable for or assume the commitments of central governments, regional, local or other public authorities, other bodies governed by public law, or public undertakings of any Member State, without prejudice to mutual financial guarantees for the joint execution of a specific project. A Member State shall not be liable for or assume the commitments of central governments, regional, local or other public authorities, other bodies governed by public law, or public undertakings of another Member State, without prejudice to mutual financial guarantees for the joint execution of a specific project." Along with Article 123 TFEU, this norm intended to potentially create a favourable backdrop, within the Treaty framework, to the maintenance, by the Member States, of controlled deficits and public spending. Article 123(1) TFEU states that "Overdraft facilities or any other type of credit facility with the European Central Bank or with the central banks of the Member States (...) in favour of Union institutions, bodies, offices or agencies, central governments, regional, local or other public authorities, other bodies governed by public law, or public undertakings of Member States shall be probibited, as shall the purchase directly from them by the European Central Bank or national central banks of debt instruments".

${ }^{63}$ In 2009, IMF experts were already expressing concerns regarding the long-term fiscal costs and effects on the fiscal sustainability of the necessary use of public resources to tackle the crisis: cf. S. Sgherri, and E. Zoli, "Euro Area Sovereign Risk During the Crisis," IMF Working Paper, WP/09/222:223 (2009): 17. 
with a joint package of bilateral loans from Member States, along with the IMF, adding up to 110 billion euros in total ${ }^{64}$, during the summit of the Heads of State Government of the euro area. Greece formally requested assistance in April 2010 and the rescue agreement was concluded in the following month involving a "troika" of institutions: the IMF, the Commission and the ECB. Therefore, the absence of a mechanism, under the EMU, to deal with the situation was unambiguously exposed and, what is more, the blocking effect of the "no bailprinciple of Article 125(1) TFEU was playing an important role in preventing Union solution to the problem at hand.

In this context, the use of the same intergovernmental approach that gave rise the assistance provided to Greece produced several agreements and instruments that were put forward in successive attempts to tackle the increasing detrimental consequences of the crisis and sovereign-debt related problems, similar to the taking place in Greece, which were already being forecasted in relation to other Member States ${ }^{65}$.

The first of these agreements came about precisely in a context of strong pressure over Irish and Portuguese bonds' yields and resulted in the of a temporary instrument, created by the Heads of State and Government of euro area, outside of the EU framework, as a company under Luxembourg law, May 2010. The European Financial Stability Facility $\left(\mathrm{EFSF}^{66}\right)$ was authorised to borrow up to 440 billion euros, reflecting, in fact, that it was designed simply to provide emergency financial support only to small peripheral countries such as Greece, Ireland and Portugal, not anticipating further and broader medium and longer-term problems arising from other Member States. In fact, in July 2011, this mechanism was amended with an increase in its capital guarantee to 780 billion euros which, as some pointed out ${ }^{67}$, would still not be enough to address

${ }^{64}$ Cf. Statement of Heads of State or Government of the euro area, Brussels 7 May 2010, accessed April 10, 2015, available at https://www.consilium.europa.eu/uedocs/cms data/docs/ pressdata/en/ec/114295.pdf; the document "Euro area and IMF agreement on financial support programme for Greece”, comprising information still remaining on the initial agreement, accessed April 10, 2015, available at http://ec.europa.eu/economy finance/articles/eu economic situation/2010-05-03statement-commissioner-rehn-imf-on-greece en.htm; cf. additionally the Economic Adjustment Programme for Greece issue by the European Commission, accessed April 10, 2015, and available at http://ec.europa.eu/economy finance/publications/occasional paper/2010/op61 en.htm, and the decisions issued aiming at increasing fiscal surveillance and pressuring Greece to correct the excessive deficit situation through adequate measures: Council Decision (2010/320/EU) of 10 May 2010, O.J. 2010, L 145/6, amended by Council Decision (2010/486/EU) of 14 Sept. 2010, O.J. 2010, L 241/12.

${ }^{65}$ Cf., e.g., A. Sieber, "The EFSM and the EFSF: Now and what Follows," Directorate General for Internal Policies, European Parliament (2010): 2, accessed April 10, 2015, available at http://www.europarl. 20100908ATT81666/20100908ATT81666EN.pdf.

${ }^{66}$ Cf. press release of the Extraordinary Council Meeting for Economic and Financial Affairs (ECOFIN), Brussels 9 and 10 May 2010, accessed April 10, 2015, available at http://europa.eu/rapid/press-release PRES-10-108 en.htm?locale=en; for details on the original EFSF cf. Annex 1 of http://www.efsf. europa.eu/attachments/faq en.pdf, accessed April 10, 2015; the decision of the Member States of the euro area meeting within the Council, Council Doc. 9614/10 of 10 May 2010, and its Articles of Incorporation accessed April 10, 2015, available at: http://www.efsf.europa.eu/attachments/efsf articles of incorporation en.pdf.

${ }^{67}$ Cf. D. Gros, and T. Mayer, "Refinancing the EFSF via the ECB," CEPS Commentary, 18 (2011): 2, accessed April 10, 2015, available at http://www.dbresearch.com/PROD/DBR INTERNET ENPROD/PROD0000000000293205/Refinancing+the+EFSF+via+the+ECB.PDF; this EFSF expansion 2.0, as it came to be commonly known, also raised additional problems regarding its approval at the national level of different Member States (e.g. Germany, Slovakia and Finland), reflecting the rising suspicions of public opinions on the different "bail-outs" taking place, and the 
further problems.

The EFSF was complemented by the European Financial Stabilisation Mechanism $\left(\mathrm{EFSM}^{68}\right)$ that would be available to provide financial assistance to Member States in difficulties, in the form of loans or credits, set up as a Commission fund ${ }^{69}$ authorised to borrow up to 60 billion euros, and mounting up up to a total of up to 500 billion euros, with an additional amount of 250 billion being provided by the IMF. The EFSM/EFSF was called to play its role at the request of Ireland ${ }^{70}$, in November 2010, and Portugal ${ }^{71}$, in March 2011. However, However, the unfolding of the crisis would demand further development of the set set of instruments available at this point and would eventually require structures of of response of a more permanent nature ${ }^{72}$. From the outset, critics pointed out that that the temporary nature of these mechanisms was one of the main reasons for their inefficacy in tackling the on-going effects of the sovereign-debt crisis. In particular the EFSF was "created and became a funding vehicle without being a real real fund" $"$ ?3.

The referred instruments and the path that would be followed to eventually replace them by a fund of a permanent nature, provided with more stable structures, and set up to tackle future financial problems with major impact on sovereign-debts and on the ability of Member States to resort to the markets, would would not, however, exhaust the array of responses to the crisis. In fact, several steps were taken during 2010 and 2011 in order to attempt to improve the framework of economic governance and surveillance based on the SGP, within the the Union's legal background, that had suffered a major credibility blow, in particular with the disclosure of the real state of Greek's public finances.

To this end, the Commission came forward, in September 2010, to present a package of legislative proposals seeking to improve and correct macroeconomic imbalances, and strengthen the SGP and the national fiscal frameworks while reenforcing fiscal discipline with the imposition of sanctions on non-compliant Member States. Additionally, and in order to improve in time inter-Member States coordination of budgetary, macro-economic and structural policies, the package introduced the so-called European semester ${ }^{74}$. Overall this group of legislative proposals, commonly known as "six pack"75 was adopted in October 2011 as a new

permanent political and legal concerns of the different Parliaments on the legality of these instruments according to the framework provided by Articles 123 and 125 TFEU (cf. infra ${ }^{69}$ ); for the Framework Agreement between the Member States of the euro area and the EFSF cf. http://www.efsf.europa.eu/attachments/20111019 efsf framework agreement en.pdf, accessed April 10, 2015.

${ }^{68}$ Cf. Council Regulation (EU) No 407/2010 of 11 May 2010 establishing a European Financial Stabilisation Mechanism, O.J. L 118/1, 12.5.2010.

${ }^{69}$ It was questioned if, considering that the EFSF/EFSM's debt is backed by the EU budget, these instruments would not constitute a violation of the legal framework provided by the TFEU; cf. Sieber, "Now and what Follows," 2-3; cf. supra ${ }^{62}$.

70 For an overview of the Irish programme cf. http://ec.europa.eu/economy finance/ assistance eu ms/ireland/index en.htm, accessed April 10, 2015.

71 For an overview of the Portuguese programme cf. http://ec.europa.eu/economy finance/ assistance eu ms/portugal/index en.htm, accessed April 10, 2015.

${ }^{72}$ Cf. infra Tittle 5.

${ }^{73}$ Cf. D. Gros, and T. Mayer, "EFSF 2.0 or European Monetary Fund?, ” CESifo DICE Report 3/ 2011 (2011): 31.

74 The "European Semester" was designed to improve in time coordination of economic and budget policies of Member States in the context of the proposed reforms to the SGP; cf. infra ${ }^{75}$.

75 The "six pack" comprised: Regulation (EU) No 1175/2011 of 16 November 2011 amending Council Regulation (EC) No 1466/97 on the strengthening of the surveillance of budgetary positions and the surveillance and coordination of economic policies; Council Regulation (EU) No 1177/2011 
surveillance framework for improving compliance in the context of the reform of the SGP and targeting emerging macro-economic imbalances.

But the instruments resulting from intergovernmental coordination, outside Union's framework, were additionally incremented, in March 2011, by the Euro $\mathrm{Pact}^{76}$ in line with the methodology that had essentially been used hitherto, with the EFSF/EFSM. Therefore, the eurozone Member States, together with non-euro area States ${ }^{77}$, agreed on a Pact, adopted in the context of the European Council of March 2011, aiming at fostering competitiveness and employment, contributing to the sustainability of public finances and reinforcing financial stability, while boosting tax policy coordination. However, and despite the fact this instrument aimed at increasing the efforts of the involved States to achieve referred major policy goals, it contained very few innovations thus having a added value ${ }^{78}$.

\section{In search of long-term solutions}

As mentioned above, the transient nature of the EFSF/EFSM, their position outside the legal and institutional framework of the Union and their limited success in calming down the turmoil that prevailed in the financial markets throughout the period that we have been refereeing to, led many to ask for additional and clearer steps to be taken. The direction and form that these further actions should take was, however, widely debated. A large-scale structured approach was, and in fact still is, always present in the proposals put forward, envisaging not only short-term solutions but also "the re-stabilisation of the European integration process" ${ }^{\text {"t9 }}$.

However, a mechanism of a more permanent and clear nature aiming at protecting the financial stability and sustainability of the euro area, was thought to entail an amendment of the TFEU, namely to its Article 136, in order to set aside any possible doubts regarding its compatibility with Article 125 TFEU and avoid the need for future referendums of unpredictable outcomes. Such amendment was agreed upon before the end of $2010^{80}$ and intended to legitimise

of 8 November 2011 amending Regulation (EC) No 1467/97 on speeding up and clarifying the implementation of the excessive deficit procedure; Regulation (EU) No 1173/2011 of 16 November 2011 on the effective enforcement of budgetary surveillance in the euro area; Council Directive 2011/85/EU of 8 November 2011 on requirements for budgetary frameworks of the Member States; Regulation (EU) No 1176/2011 of 16 November 2011 on the prevention and correction of macroeconomic imbalances; and Regulation (EU) No 1174/2011 of 16 November 2011 on enforcement measures to correct excessive macroeconomic imbalances in the euro area.

${ }^{76}$ Cf. Conclusions of the European Council of 24 and 25 of March 2011, accessed April 10, 2015, available at http://www.consilium.europa.eu/uedocs/cms data/docs/pressdata/en/ec/120296.pdf.

77 Bulgaria, Denmark, Latvia, Lithuania, Poland and Romania; Latvia and Lithuania joined the eurozone in 2014 and 2015, respectively.

78 Cf. S. Verhelst, "The Reform of European Economic Governance: Towards a Sustainable Monetary Union?," Egmont Paper 47, Egmont - Royal Institute for International Relations, Gent, Academia Press (2011): 49.

${ }^{79}$ In this sense cf., as a paradigmatic example cf., K. Busch and D. Hirschel, "Europe at the Crossroads: Ways Out of the Crisis", International Policy Analysis, Berlin, Friedrich-Ebert-Stiftung, (2011): 1.

80 Cf. Conclusions of the European Council of 16 and 17 of December 2010, accessed April 10, 2015, available at http://www.consilium.europa.eu/uedocs/cms data/docs/pressdata/en/ec/ 118578.pdf\#page=6. The two line amendment to Article 136 stated that "The member states whose currency is the euro may establish a stability mechanism to be activated if indispensable to safeguard the stability of the euro area as a whole. The granting of any required financial assistance under the mechanism will be made subject to strict conditionality." And was adopted during the European Council of 25 March 2011 (cf. European Council Decision (2011/199/EU) amending Article 136 of the Treaty on the Functioning of the 
Member States to set up a mechanism, through the use of intergovernmental cooperation, aiming the fulfillment of goals entailed by the functioning of the Union, namely the need for euro area Member States to set up a European Stability Stability Mechanism $\left(\mathrm{ESM}^{81}\right)$, intended to replace the EFSF/EFSM as many had been claiming.

Additionally, in July 2011, the situation in Greece that had never left the main stage of the turmoil in the markets and that would require further financial assistance, only came to strengthen the need for such mechanism, The new rescue rescue to Greece would not make use of bilateral loans, as its predecessor, but would instead involve the EFSF/EFSM, the IMF and the private sector ${ }^{82}$.

However, the doubts regarding the legality of several steps taken and instruments adopted ${ }^{83}$ while paving the way to the ESM would not be completely cast aside. Some went as far as globally stating that the decisions to financially rescue Greece in 2010 and 2011, the establishment of the EFSF and the support for for Ireland and Portugal were all in breach of EU law ${ }^{84}$. Regardless of the criticism criticism raised, and still ongoing, the ESM has already provided financial assistance to the financial systems of both Spain ${ }^{85}$ and Cyprus ${ }^{86}$.

Furthermore, and alongside the negotiations undertaken to achieve the ESM, there remained concerns regarding the strengthening of the SGP in the long run ${ }^{87}$. Against this backdrop, the intergovernmental approach was equally used to negotiate an additional treaty - Treaty on Stability, Coordination and Governance in the Economic and Monetary Union (TSCG ${ }^{88}$ ) - intended to co-exist with the ESM. The Fiscal Compact, as it came to be known, was signed on 2 March 2012 by all

European Union with regard to a stability mechanism for Member States whose currency is the euro, O.J. L 91/11), in what came to be known as the "TFEU amendment" treaty.

81 The European Council first agreed on the need for euro area Member States to establish a stability mechanism of a permanent nature in December 2010 (cf. Conclusions of the European Council of 16 and 17 of December 2010, accessed April 10, 2015, available at http://www.consilium.europa.eu Luedocs/ cms data/docs/pressdata/en/ec/118578.pdf\#page=6). However, the Treaty Establishing the European Stability Mechanism, comprising the details regarding the functioning of the ESM, concluded exclusively by Eurozone Member States, only came into force on 27 September 2012 in its second version. In fact, a first version had been agreed upon in July 2011 but was further developed largely in result of the deepening of the euro debt-crisis. For further details on the ESM, set up as an international organisation located in Luxembourg, and the consolidated version of the ESM Treaty cf. http://www.esm.europa.eu/index.htm, accessed April 10, 2015.

82 Cf. Statement by the Eurogroup of 20 June 2011, accessed April 10, 2015. available at http://www.consilium.europa.eu/uedocs/cms data/docs/pressdata/en/ecofin/122908. pdf, followed by European Council of 23 and 24 June 2011, Conclusions, Doc. EUCO 23/11, para 15; cf. additionally, the Statement by the Heads of State or Government of the euro area and EU institutions, Council of the European Union, 21 July 2011, points 1 to 7, accessed April 10, 2015, available at https://www.consilium.europa.eu/uedocs/cms data/docs/pressdata/en/ec/123978.p df.

${ }^{83}$ In this regard see in particular the issues raised regarding the validity of the amendment treaty, concerns related with its relation with the entry into force when faced with the ESM, and the legality of the ESM itself within the legal framework of the EU, assessed in the context of Judgment Pringle, 27 November 2012, Case C-370/12.

${ }^{84}$ Cf., in this sense, e.g., Matthias Ruffert, "The European debt crisis and European Union law" (48) Common Market Law Review, Issue 6, pp. 1777-1805 (2011): 1785.

${ }^{85}$ For an overview of the assistance provided to Spain cf. http://www.esm.europa.eu/assistance/ spain/index.htm, accessed April 10, 2015.

${ }^{86}$ For an overview of the assistance provided to Cyprus cf. http://www.esm.europa.eu/assistance/ cyprus/index.htm.

${ }^{87}$ Cf. supra Tittle 4.

${ }^{88}$ Cf. http://ec.europa.eu/economy finance/articles/governance/2012-03-14 six pack en.htm, accessed April 10, 2015. 
Member States of the EU, except the Czech Republic and the United Kingdom, and is perceived to have been intentionally set up as a stricter version of the SGP run alongside the "six-pack".

\section{The ECB-and the crisis}

As it has been mentioned, the objectives of setting up the ESCB and the ECB were to contribute to the financial stability policies of the competent authorities without prejudice of the prime goal of maintaining price stability ${ }^{89}$. However, as financial crisis unfolded, it became clear that the biggest challenges arising from were sovereign debt related.

In fact, in 2010, the ECB adopted a Securities Markets Programme (SMP ${ }^{90}$ ) the acquisition of government bonds, in open market, to ensure debt and in those market segments which were deemed dysfunctional. In August 2012, with the same end, the ECB announced ${ }^{91}$ that this programme would be replaced undertaking Outright Monetary Transactions (OMT) in secondary, sovereign markets.

These ECB's bond-buying plans have been, from the outset, strongly by some circles as an infringement of the monetary financing prohibition of 123 TFEU, facing strong opposition from some political sectors, namely in Germany, and even being the subject of legal dispute ${ }^{92}$. However, they have also been the most effective instruments when trying to put aside the ups and downs the markets arising from the lack of confidence in the sovereign debt of euro countries. This was particularly clear in the context of the relative ineffectiveness the succession of meetings, statements, legal and political instruments put by the Members States throughout the crisis.

These are, nonetheless, extremely controversial instruments, particularly in a political environment where the opposition, among the Member States, between rescued and rescuers seems to be particularly easy to exploit by populist political parties whose influence seems to be increasingly growing in the European political arena. Such an environment is directly linkable to the extension of the instruments put forward by the ECB and the context in which it did so.

Additionally, the EU also reformed the architecture for financial supervision aiming to prevent further financial crises and to support monetary and fiscal policies. The experience acquired through the financial events comprised in the first stages of the crisis showed to what extent a debacle of the private finance sector can further weaken fragile public budgets by forcing governments to rescue banks, financial institutions and strategic companies, being therefore perceived as being an instrumental reform to accomplish long-term financial stability. The reform replaced the so-called Lamfalussy framework of committees with new European agencies: the European Systemic Risk Board (ESRB) and three new European independent authorities (the European Securities and Markets Authority, the European Insurance and Occupational Pensions

\footnotetext{
${ }^{89}$ Cf. supra Tittle 3.

${ }^{90}$ Decision (2010/281/EU) of the European Central Bank of 14 May 2010 establishing a securities markets programme, O.J. 2010, L 124/8.

91 Cf. ECB's press release of 6 September 2012 on Technical features of Outright Monetary Transactions accessed April 10, 2015, available at http://www.ecb.europa.eu/press/pr/date/2012 /html/pr120906 1. en.html.

${ }^{92}$ See in particular the on-going controversy involving the Court of Justice in the Case C-62/14, Peter Gauweiler and Others, request for a preliminary ruling from the Bundesverfassungsgericht (Germany) lodged on 10 February 2014.
} 
Authority, and the European Banking Authority ${ }^{93}$, already developing their activities.

These instruments, together with the mechanisms developed in the described context of strengthening of the SGP-related goals, are expected to prevent future crisis. However, throughout the crisis, the ECB, although clearly identifying the cause of the events as excessive deficits and debts, facing the absence of instruments to be put in place immediately, was faced with decisions regarding the extension of its own possible actions. Other highly controversial proposals have been consistently put forward, like the creation of a framework that allows the setup of a European Monetary Fund or even the issuing of Eurobonds. This conundrum and the way the EU has been choosing to face it, encompasses the main challenges that the EMU and the EU as a whole will be facing in its near future.

\section{Final remarks: dwelling on the past or embracing the future}

It is undeniable that EMU has been facing, in the most recent years, a complex challenge that goes to the point of creating a consistent backdrop for doubts to be raised on its reliability and capacity to survive the storm. Many have been predicting its end, certain that the EU framework on the matters of economic and financial policies will continue to fail to cast away the doubts and suspicions that have been thrown upon it.

For historical, political and economic reasons, EU member states as a whole have never been consistently prone to follow many of the critics' suggestions that considered the link between economic and financial policies within the framework of the EU as a basic condition for the survival of the EMU in the long run.

In fact, when facing the turmoil of the financial markets and its consequences, the EU and the ECB appear to be poorly equipped to deal with a set of circumstances that seem to be pushing it further in the direction of answering to a recurrent conundrum of the integration process: to move forward towards the deepening of the Union, linking economic governance to the core of the EU integration, assuming its inevitable political consequences and therefore paving the way to a legal structure more reminiscent of a federalist approach, or avoiding, once again, that Pandora's Box by insisting in an intergovernmental approach?

Many have also been those claiming that re-fixing the current equilibrium of EU and ECB competences on the matters of economic vs. financial affairs will certainly interfere with the touchstone of a sane monetary Union: the independence of its central bank. Such line of reasoning, that tends to be closer to the current German school of thought based on strict budgetary rules and a conservative intervention of the ECB in the markets, seems to have been preventing the EU from finding a permanent and more striking solution for the on-going crisis, avoiding instruments that some have been putting forward like issuing Eurobonds or creating a European Monetary Fund. An already relatively long list of weak and unsuccessful attempts in the form of public official statements, agreements, pacts and treaties - to sort out the crisis and its outcomes, shows the need for more effective and prevailing

\footnotetext{
${ }_{93}$ See, respectively, Regulations (EU) No 1093/2010 (establishing a European Banking Authority), Regulations (EU) No 1094/2010 (establishing a European Insurance and Occupational Pensions Authority) and Regulation (EU) No 1095/2010 (establishing a European Securities and Markets Authority), in O.J. L 331.
} 
answers that will inevitably be politically more difficult, as the popularity of political movements bluntly against the strengthening of the European construction increases.

With this backdrop of a discontent public opinion starting to reflect in the extremes of the political spectrum in elections across the Union and the uncertainty of the endurance of the current proposals being debated and voted, we are forced to believe that such answers are, unfortunately, yet to be found. 